\title{
Spraying hydroponic lettuce roots with a suspension concentrate formulation of Bacillus velezensis to suppress root rot disease and promote plant growth
}

\author{
M. Kanjanamaneesathian ${ }^{1}$, R. Wiwattanapatapee ${ }^{2}$, W. Rotniam ${ }^{3}$ and \\ W. Wongpetkhiew ${ }^{4}$ \\ ${ }^{1}$ Plant Production Technology Program, Faculty of Animal Science and Agricultural Technology, \\ Silpakorn University, Phetchaburi IT campus, Cha-Am, Phetchaburi, Thailand \\ ${ }^{2}$ Department of Pharmaceutical Technology, Faculty of Pharmaceutical Science, Prince of \\ Songkla University, Hatyai campus, Songkhla, Thailand \\ ${ }^{3}$ Institute of Community Operation for Integrated Studies, Thaksin University, Muang, \\ Songkhla, Thailand \\ ${ }^{4}$ Faculty of Animal Science and Agricultural Technology, Silpakorn University, Phetchaburi IT \\ campus, Cha-Am, Phetchaburi, Thailand \\ Corresponding author: kmana@su.ac.th
}

\begin{abstract}
Bacillus velezensis was prepared as a suspension concentrate (SC) and sprayed on to the roots of 1-month-old Lactuca sativa, grown in a hydroponic system. In the first experiment using Lactuca sativa (var. Red Coral) with root rot symptoms, a $1 \%$ blank with no cells, a $1 \%$ SC $\left(10^{13} \mathrm{CFU} / \mathrm{ml}\right)$ and $1 \%$ fresh bacterial cells (FC) $\left(10^{14} \mathrm{CFU} / \mathrm{ml}\right)$ reduced the percentage of root tips colonized by the pathogen and increased the fresh shoot weight compared to plants that were not sprayed. In the second experiment with L. sativa (var. Green Oak) using healthy-looking roots, a 1\% blank, $10 \%$ SC $\left(10^{13} \mathrm{CFU} / \mathrm{ml}\right)$ and $1 \%$ FC of the bacterium $\left(10^{14} \mathrm{CFU} / \mathrm{ml}\right)$ reduced the percentage of root tips colonized by Pythium sp. The SC and FC of the bacterium increased the fresh shoot weight, while the blank, the SC and the FC of the bacterium increased the dried weight of the shoot.
\end{abstract}

Keywords Bacillus velezensis, hydroponic vegetables, root rot disease, suspension concentrate.

\section{INTRODUCTION}

Biological control is an alternative to the use of chemical pesticides to control plant diseases (Cook \& Baker 1983). Nevertheless, the possible implementation of this measure relies upon the availability of an effective biological-based product, the application of which must be cost competitive compared to the use of any chemical pesticides (Schisler et al. 2004).

Crops grown hydroponically have succumbed to root rot diseases caused by plant pathogens such as Aphanomyces sp., Fusarium spp., Pythium spp. and Phytophthora spp. (Khalil \& Alsanlus 2010). Four species of Pythium spp., including $P$. carolinianum, $P$. dissotocum, $P$. helicoides and $P$. myriotylum, caused very severe root rot disease of vegetables grown hydroponically in Thailand (Kanghae 2010). These soil-borne plant pathogens, either individually or as a combination, may have contaminated the growing system and initiated infection to roots of the plants. 
Pathogens may spread very quickly in the growing system through the movement of recirculated nutrients supplied for supporting plant growth. The pathogens may remain in the hydroponic growing facilities through either the long term surviving structures, such as oospores and chlamydospores, or mycelia in diseased plant tissues. Both the surviving structures and the mycelia in diseased tissues contaminating the growing system, will serve as a source of a primary inoculum that will initiate infection in roots of the following crops. Understanding the disease complex that is prone to occur in a hydroponic growing system and the conditions that are conducive for disease development are the challenges in implementing measures for disease control (Kanghae 2010).

The limited amount of research in both adopting biological control measures and inventing the most effective formulations for controlling diseases in crops produced in hydroponic systems limits the ability to use a biological approach to manage plant diseases in greenhouses and hydroponic systems. This limitation, however, provides a challenge to researchers to identify novel effective antagonists, devise applicable formulations and seek appropriate ways to deliver the formulations to the target site with an expected control efficacy in crops grown hydroponically.

Research into biological and other nonchemical control measures to deal with plant disease problems in crops grown hydroponically have been reported (Rankin \& Paulitz 1994; Grosch et al. 1999; Zhao et al. 2000; De Jonghe et al. 2005; Liu et al. 2007; Ogai et al. 2009; Khalil \& Alsanlus 2010). In Thailand, research with respect to the formulation of effective biological agents to control plant pathogens has been carried out with Trichoderma harzianum to control damping-off of cucumber (Intana 2003). The product of this fungal antagonist has been subsequently used to control root rot disease in the hydroponic growing system.

A bacterial antagonist product, the suspension concentrate (SC) of Bacillus velezensis, has been devised and subject to tests in the laboratory and under hydroponic growing conditions in Thailand (Kanjanamaneesathian et al. 2013). In a preliminary study, SC formulations have been shown to be effective in controlling root rot disease of Lactuca sativa caused by $P$. aphanidermatum in laboratory conditions (Kanjanamaneesathian et al. 2013).

This research aims to further test the efficacy of spraying a SC of Bacillus velezensis to both suppress root rot disease and to promote the growth of $L$. sativa in the hydroponic dynamic root floating technique (DRFT) growing system.

\section{MATERIALS AND METHODS}

\section{Antagonistic bacteria}

Bacillus velezensis (No. 129 C/1), the bacterium able to inhibit the growth of $P$. aphanidermatum and $P$. helicoides, was chosen for developing an appropriate formulation (Kanjanamaneesathian et al. 2010; Kanjanamaneesathian et al. 2013). This bacterium was also selected based upon its capacity to produce indole-3- acetic acid (IAA) (Abd El-Azeem et al. 2007), a facilitator of plant growth.

\section{Preparation of the FC and SC formulations}

The FC of $B$. velezensis was prepared by transferring a loopful of a 1-day-old culture of the bacterium on potato dextrose agar (PDA) to $100 \mathrm{ml}$ of sterile water in the flask. Two $\mathrm{ml}$ of this bacterial suspension was transferred to flasks containing $50 \mathrm{ml}$ of PDA. These flasks were incubated at $37^{\circ} \mathrm{C}$ for 4 days, after which the bacterial cells were dislodged from the surface of the medium with sterile water. The cell suspension of the bacterium was initially centrifuged at 3,000 rpm for $10 \mathrm{~min}$, followed by another three centrifugations (at 3,000 rpm) in sterile water. This bacterial suspension was subsequently incubated in the water bath at $80^{\circ} \mathrm{C}$ for $20 \mathrm{~min}$. The number of endospores of the bacterium was enumerated with a drop plate technique on a plate count agar (PCA) (Zuberer 1994). This endospore was stored in the refrigerator at $5^{\circ} \mathrm{C}$ until used for the preparation of the SC formulation.

The SC formulation of $B$. velezensis was prepared according to the protocol described 
earlier (Kanjanamaneesathian et al. 2013). An optimum SC of B. velezensis contained $10^{12} \mathrm{CFU} /$ $\mathrm{ml}$ endospores $(400 \mathrm{ml})$, sterile water $(500 \mathrm{ml})$ and $5 \%$ xanthan gum $(\mathrm{w} / \mathrm{v})(100 \mathrm{ml})$. These components were mixed using a magnetic stirrer until a uniform suspension was obtained. A SC formulation, without endospores, was also prepared and used in the following efficacy test (as a blank). This blank (no cells), the SC and a FC were used to determine both the efficacy of the bacterium to suppress root rot disease and the degree of growth promotion of L. sativa in the dynamic root floating technique (DRFT) hydroponic system.

\section{Characteristics of the DRFT system}

The DRFT system at Phetchaburi College of Agriculture and Technology, Cha-Am, Phetchaburi, Thailand, was used in this experiment. The DRFT system was an elevated hydroponic growing facility (dimension $2.10 \times$ $7.30 \times 2.25 \mathrm{~m}$.), covered with a transparent plastic sheet on the top as roofing and an insect netting screen on all four sides to protect the vegetables from rainfall and insect pests respectively. The upper part of this facility, standing $0.85 \mathrm{~m}$ above the ground and containing nutrient solution (500 litres), was used to raise vegetable seedlings. A plastic tank (with an overall capacity of 1000 litres and containing a portion of nutrient solution (500 litres) was installed beneath the facility to provide a nutrient solution for plant growth. The nutrient solution consisted of the 12 essential elements for plant growth, i.e. N (269 ppm), $\mathrm{P}$ (52 ppm), K (329.6 ppm), Mg (47.1 ppm), $\mathrm{S}$ (65 ppm), Fe (4.1 ppm), Mn (0.7 ppm), B (0.2 ppm), Zn (0.2 ppm), Cu (0.2 ppm), $\mathrm{Mo}(0.002 \mathrm{ppm})$ and $\mathrm{Ca}(180 \mathrm{ppm}$.). This nutrient solution (at pH 6.5 and EC 2.0) was taken from the tank and discharged to the growing facility above. Excessive nutrient solution returned to the tank below via a draining duct.

Seeds of vegetables (L. sativa) were germinated on a water-soaked sponge in a plastic micro-pot tray (with a cross slit-opening bottom to allow for root growth) for 7 days in the seedling house. After germination, 25 seedlings were removed from the tray and each placed into a hole of a Styrofoam floating platform (dimension $60 \times$ $94 \mathrm{~cm}$.). Each DRFT facility had the capacity to contain 24 Styrofoam floating platforms. These vegetable seedlings on the platforms were cultivated for 40 days in the DRFT system after which the crops were harvested.

\section{Spraying the SC and FC on the roots of L. sativa} In the first test, 12 Styrofoam floating platforms with each platform containing 25 L. sativa (var. Red Coral) growing for 30 days on the DRFT system were used in the experiment. The experiment was conducted with L. sativa showing severe root rot symptoms. Three platforms were sprayed with either a $1 \%$ blank (v/v) (1\% blank), a $1 \% \mathrm{SC}\left(10^{13} \mathrm{CFU} / \mathrm{ml}\right)(\mathrm{v} / \mathrm{v})$ or a $1 \% \mathrm{FC}$ of B. velezensis $\left(10^{14} \mathrm{CFU} / \mathrm{ml}\right)(\mathrm{v} / \mathrm{v})$, while the other three platforms served as non-treated controls.

The Styrofoam floating platform was temporarily lifted out of the nutrient medium (on the side at the edge of the DRFT system) to expose the vegetables roots. These roots were then sprayed with $500 \mathrm{ml}$ (per platform) of either blank, SC or FC of the bacterium. After spraying, the platform was gently placed back on to the DRFT system and the vegetables were grown until an assessment for disease and growth was conducted.

In the second test, eight Styrofoam floating platforms with each platform containing 25 L. sativa (var. Green Oak) growing for 30 days on the DRFT system were used. The experiment was conducted with $L$. sativa showing healthylooking roots. Other experimental details were similar to those described above, except that two platforms were sprayed with either a $1 \%$ blank (v/v) (1\% blank), a $10 \%$ SC $\left(10^{13} \mathrm{CFU} / \mathrm{ml}\right)(\mathrm{v} / \mathrm{v})$ or a $1 \% \mathrm{FC}$ of $B$. velezensis $\left(10^{14} \mathrm{CFU} / \mathrm{ml}\right)(\mathrm{v} / \mathrm{v})$, while the other two platforms served as nontreated controls.

\section{Assessing root rot disease and growth of $L$. sativa For assessment of the efficacy of the SC and FC to suppress root rot, either six L. sativa (var. Red Coral) with root rot symptoms or two L. sativa (var. Green Oak) growing in the centre of the}


platform, were randomly sampled at 7 days after being sprayed with the formulations. Ten pieces of root tip from each L. sativa plant were aseptically excised and plated onto PDA. The numbers of colonized root tips, showing growth of Pythium sp. on PDA, were counted 1 day after incubation and the percentage of colonized root tips with the growing fungus was calculated and compared between treatments.

The plants in the remaining platforms of each experiment were used for growth assessment. Nine of the L. sativa (var. Red Coral) with root rot symptoms were randomly sampled to assess the weights of both the shoots and roots. Six and three of L. sativa (var. Green Oak) with healthylooking roots were randomly sampled to assess the root and shoot weight, respectively.

The shoot and root parts were separated and immediately weighed. These plant parts were then subsequently dried in a hot air oven at $50^{\circ} \mathrm{C}$ for $48 \mathrm{~h}$ before being reweighed.

\section{Statistical analysis}

Data collected were subjected to statistical analysis using the SAS Software Program (Version 9.1). A mean value $( \pm S E)$ of the percentage of root tips of L. sativa (var. Red Coral and var. Green Oak) colonized by the pathogen and the fresh and dry weights of both shoots and roots were compared using the Duncan Multiple Range Test (DMRT).

\section{RESULTS}

\section{Efficacy of the SC and FC with $L$. sativa}

Spraying the roots of L. sativa (both var. Red Coral and var. Green Oak) with either blank $1 \%$ SC, $10 \%$ SC or FC effectively reduced the percentage of root tips colonized by the pathogen compared to the control plants that were not sprayed (Tables 1 \& 2). The blank and 1\% SC were as effective as $\mathrm{FC}$ in reducing the percentage of root tips colonized when they were applied to the root of L. sativa (var. Red Coral) that were severely infected and colonized by the pathogen (Table 1). However, the efficacy of the treatment was more prominent when healthy-looking roots of L. sativa (var. Green Oak) were sprayed with a $10 \%$ SC, with a reduction of the percentage of root tips colonized to $20 \%$ compared with that of the control (95\%) (Table 2).

Table 1 Mean $( \pm S E)$ percentage of root tips of L. sativa (var. Red Coral) colonized by the pathogen 7 days after spraying roots that showed severe root rot symptoms. Means in each column followed by the same letter are not significantly different at $\mathrm{P}=0.05$.

\begin{tabular}{lc}
\hline Treatment & \% colonized root tips $(\mathrm{n}=24)$ \\
\hline Control & $88.3 \pm 5.9 \mathrm{a}$ \\
$1 \%$ blank & $65.0 \pm 4.2 \mathrm{~b}$ \\
$1 \%$ SC & $60.0 \pm 8.4 \mathrm{~b}$ \\
$1 \%$ FC & $60.0 \pm 6.3 \mathrm{~b}$ \\
\hline
\end{tabular}

Table 2 Mean $( \pm \mathrm{SE})$ percentage of root tips of L. sativa (var. Green Oak) colonized by the pathogen 7 days after spraying healthy looking roots. Means in each column followed by the same letter are not significantly different at $\mathrm{P}=0.01$.

\begin{tabular}{lc}
\hline Treatment & \% colonized root tips $(\mathrm{n}=8)$ \\
\hline Control & $95.0 \pm 3.5 \mathrm{a}$ \\
$1 \%$ blank & $65.0 \pm 3.5 \mathrm{~b}$ \\
$10 \%$ SC & $20.0 \pm 0.0 \mathrm{c}$ \\
$1 \%$ FC & $45.0 \pm 3.5 \mathrm{bc}$ \\
\hline
\end{tabular}

Spraying the diseased roots of $L$. sativa (var. Red Coral) with either blank, a 1\% SC or FC effectively increased the fresh weight of the shoot. However, only the blank increased the shoot dry weight of L. sativa (var. Red Coral) (Table 3). FC increased the fresh root weight, while both SC and FC enhanced the root dry weight (Table 3 ).

The efficacy of the treatments in the growth promotion test was more prominent when healthy-looking roots of $L$. sativa (var. Green Oak) were sprayed with $10 \%$ SC and FC, with the increment in shoot fresh weight being $30.6 \mathrm{~g}$ and $57.6 \mathrm{~g}$ respectively, compared with that of the control (Table 4). FC was highly effective in increasing the shoot dry weight, compared with the control (Table 4). While only 10\% SC and FC increased the fresh root weight, all three treatments enhanced root dry weight (Table 4). 
Table 3 Mean $( \pm S E)$ of the fresh and dry weight of both roots and shoots of L. sativa (var. Red Coral) at 14 days after spraying the treatments. Means in each column followed by the same letter are not significantly different fat $\mathrm{P}=0.01$.

\begin{tabular}{lcccccc}
\hline & \multicolumn{2}{c}{ Fresh weight $(\mathrm{g})$} & & \multicolumn{2}{c}{ Dry weight $(\mathrm{g})$} \\
\cline { 2 - 3 } \cline { 5 - 6 } Treatment & Root $(\mathrm{n}=36)$ & Shoot $(\mathrm{n}=36)$ & & Root $(\mathrm{n}=36)$ & Shoot $(\mathrm{n}=36)$ \\
\hline Control & $6.3 \pm 1.5 \mathrm{~b}$ & $29.6 \pm 3.0 \mathrm{c}$ & & $0.4 \pm 0.0 \mathrm{~b}$ & $1.5 \pm 0.1 \mathrm{~b}$ \\
$1 \%$ blank & $7.0 \pm 0.4 \mathrm{ab}$ & $48.5 \pm 2.3 \mathrm{a}$ & & $0.5 \pm 0.0 \mathrm{ab}$ & $2.0 \pm 0.3 \mathrm{a}$ \\
$1 \%$ SC & $6.9 \pm 0.7 \mathrm{ab}$ & $41.0 \pm 2.8 \mathrm{~b}$ & & $0.6 \pm 0.0 \mathrm{a}$ & $1.8 \pm 0.1 \mathrm{ab}$ \\
$1 \%$ FC & $8.3 \pm 0.7 \mathrm{a}$ & $40.8 \pm 2.0 \mathrm{~b}$ & & $0.6 \pm 0.0 \mathrm{a}$ & $1.8 \pm 0.2 \mathrm{ab}$ \\
\hline
\end{tabular}

Table 4 Mean $( \pm S E)$ of fresh and dry weights of both roots and shoots of L. sativa (var. Green Oak) at 14 days after spraying the treatments. Means in each column followed by the same letter are not significantly different at $\mathrm{P}=0.05$.

\begin{tabular}{lccccc}
\hline & \multicolumn{2}{c}{ Fresh weight $(\mathrm{g})$} & & \multicolumn{2}{c}{ Dry weight $(\mathrm{g})$} \\
\cline { 2 - 3 } \cline { 5 - 6 } Treatment & Root $(\mathrm{n}=24)$ & Shoot $(\mathrm{n}=12)$ & & Root $(\mathrm{n}=24)$ & Shoot $(\mathrm{n}=12)$ \\
\hline Control & $11.3 \pm 0.6 \mathrm{~b}$ & $40.1 \pm 2.1 \mathrm{c}$ & & $0.6 \pm 0.1 \mathrm{~b}$ & $1.9 \pm 0.1 \mathrm{c}$ \\
1\% blank & $11.3 \pm 0.7 \mathrm{~b}$ & $58.5 \pm 2.9 \mathrm{bc}$ & & $1.2 \pm 0.2 \mathrm{a}$ & $2.9 \pm 0.1 \mathrm{~b}$ \\
$10 \%$ SC & $14.8 \pm 0.8 \mathrm{a}$ & $70.7 \pm 7.6 \mathrm{ab}$ & & $1.1 \pm 0.2 \mathrm{a}$ & $2.7 \pm 0.1 \mathrm{~b}$ \\
$1 \%$ FC & $14.2 \pm 0.6 \mathrm{a}$ & $97.7 \pm 5.5 \mathrm{a}$ & & $1.1 \pm 0.2 \mathrm{a}$ & $8.8 \pm 0.3 \mathrm{a}$ \\
\hline
\end{tabular}

\section{DISCUSSION}

One practical requirement for achieving biological control of plant pathogens is an effective means of applying antagonists. This may include soaking seeds and drenching soil with formulations or fresh cells to target the plant (Cook \& Baker 1983). The aim is to deliver the antagonistic micro-organisms to the site where they will effectively interfere with disease development, either by preventing attachment of the pathogen to plant tissue or by suppressing growth of the pathogen both outside and inside the plant tissue.

Treating tomato plants with $B$. subtilis at the beginning of disease development reduced disease severity caused by $P$. aphanidermatum in soilless culture (Grosch et al. 1999). Pseudomonas fluorescens and other commercial products were effective antagonists against $P$. aphanidermatum and P. ultimum when these antagonists were applied before the inoculation of pathogens (Khalil \&Alsanlus 2010). Applying a rhamnolipidbased biosurfactant, an extracellular metabolite of $P$. aeruginosa with surfactant properties, was effective in controlling the spread of Phytophthora cryptogea in the hydroponic forcing system of witloof chicory (Cichorium intybus var. foliosum) (De Jonghe et al. 2005).

In this study both SC and FC formulations of $B$. velezensis, which were sprayed onto the roots of matured lettuce plants, showed that this alternative mode of applying antagonists was effective in suppressing root rot pathogens in the DRFT hydroponic system. The results indicated that a blank, SC and FC of the bacterium were effective in reducing the percentage of root tips colonized with the pathogen, both for the diseased roots of L. sativa (var. Red Coral) and healthy-looking roots of L. sativa (var. Green Oak) (Tables $1 \& 2$ ). The efficacy of the treatment in reducing the percentage of pathogen-colonized root tips was more prominent when the $10 \%$ SC was sprayed to healthy-looking roots of L. sativa (var. Green Oak) (Table 2). This suggests that, regardless of root condition (diseased or healthylooking), spraying may have protected the root from zoospore attachment and subsequent pathogen colonization. The SC should be sprayed onto the root of L. sativa when the root is still healthy to maximize control efficacy. It is possible that direct contact between the plant root and 
the antagonist led to a subsquent establishment of the bacterial population on the root surface. It has been reported that a solution of xanthan gum obtained by dissolution at moderate temperature was highly viscous (García-Ochoa et al. 2000). The SC, with dissolved xanthan gum as an ingredient, will have increased viscosity, leading to the improved adhesion of the sprayed SC onto roots of $L$. sativa. The mode of action of the treatments, however, requires further laboratory investigation. Spraying the formulations to the root of the matured plants in a DRFT system may be cumbersome as the practice requires more labor input, the mechanization and the development of an automatic system to apply the formulations may mitigate this obstacle. The effect of the blank to increase both shoot fresh and shoot dry weight of L. sativa (var. Red Coral) and only shoot dry weight of L. sativa (var. Green Oak) may be due to the effect of xanthan gum on the pathogen. Alternatively, xanthan gum may act as an elicitor to induce resistance against root rot disease as xanthan gum has been reported to induce resistance in barley against Bipolaris sorokiniana (Antoniazzi et al. 2008).

Spraying the blank, SC or FC of bacterium to the diseased root of L. sativa (var. Red Coral) increased the fresh weight of the plant shoots (Table 3). The ability to increase the fresh and dry weight of the plant was more obvious with the blank, 10\% SC and FC of the bacterium when they were sprayed on healthy-looking roots of L. sativa (var. Green Oak) (Table 4). The enhanced yield caused by the treatment, particularly that of the SC and FC, was possibly due to $B$. velezensis producing IAA, a plant growth promoting hormone (Abd El-Azeem et al. 2007). Nevertheless, it was reported that application of $B$. velezensis in nutrient solution did not affect the yield of $L$. sativa (baby leaf lettuce) grown in the hydroponic system, although the application had the beneficial effect of reducing the nitrate content in the leaf of this lettuce (Balanza et al. 2011).

\section{ACKNOWLEDGEMENTS}

This research is funded by The National Research Council of Thailand (NRCT), through Silpakorn University Research and Development Institute (SURDI). We would like to thank Dr Brian Hodgson for assistance with the English proofreading.

\section{REFERENCES}

Abd El-Azeem SAM, Mehana TA, Shabayek AA 2007. Some plant growth promoting traits of rhizobacteria isolated from Suez Canal region, Egypt. Proceedings of the African Crop Science Conference. Pp. 1517-1525.

Antoniazzi N, Deschamps C, Bach EE 2008. Effect of xanthan gum and allicin as elicitors against Bipolaris sorokiniana on barley in field experiments. Journal of Plant Disease and Protection 3: 104-107.

Balanza V, Martinez JA, Conesa E, Egea-Gilabert C, Niñirola D, López-Marín J, González A, Fernández JA 2011. Effect of PGPR application and nitrogen doses on babyleaflettuce grown in a floating system (abstract only). International Symposium on Advanced Technologies and management Towards Sustainable Greenhouse Ecosystems: Greensys 2011. http://www. actahort.org/books/952/952_86.htm (accessed 15 May 2014).

Cook RJ, Baker KF 1983. The nature and practice of biological control of plant pathogens. American Phytopathological Society, St.Paul MN. 589 p.

De Jonghe K, De Dobbelaere I, Sarrazyn R, Höfte M 2005. Control of Phytophthora cryptogea in the hydroponic forcing of witloof chicory with the rhamnolipid-based biosurfactant formulation PRO1. Plant Pathology 54: 219-226.

García-Ochoa F, Santos VE, Casas JA, Gómez E 2000. Xanthan gum: production, recovery, and properties. Biotechnology Advances 18: 549-579.

Grosch R, Junge H, Krebs B, Bochow H 1999. Use of Bacillus subtilis as a biocontrol agent. III. Influence of Bacillus subtilis on fungal root diseases and on yield in soilless culture. Journal of Plant Diseases and Protection 106: 568-580. 
Intana W 2003. Selection and development of Trichoderma spp. for high glucanase, antifungal metabolites producing and plant growth promoting isolates for biological control of cucumber damping-off caused by Pythium spp. Doctor of Philosophy Dissertation (Plant Pathology). Kasetsart University, Thailand. 202 p.

Kanghae P 2010. Effect of ammonium on root rot disease of lettuce (Lactuca sativa L.) caused by Pythium spp. in hydroponic system. Master of Science thesis (Soil Resource Management). Prince of Songkla University, Thailand. 75 p.

Kanjanamaneesathian M, Wiwattanapatapee R, Pengnoo A, Rotniam W, Kanghae P, Sawangsri P 2010. Potential of Bacillus spp. for controlling root rot disease caused by Pythium helicoides in vegetables produced in hydroponic condition (abstract only). Proceedings of the $5^{\text {th }}$ Thai Mycological Conference. p. 80.

Kanjanamaneesathian M, Wiwattanapatapee R, Pengnoo A, Rotniam W, Wongpetkhiew W, Tamala V 2013. Application of a suspension concentrate formulation of Bacillus velezensis to control root rot of hydroponically-grown vegetables. New Zealand Plant Protection 66: 229-234.

Khalil S, Alsanlus BW 2010. Evaluation of biocontrol agents for managing root diseases on hydroponically grown tomato. Journal of Plant Diseases and Protection 117: 214-219.
Liu W, Sutton JC, Grodzinski B, Kloepper JW, Reddy MS 2007. Biological control of Pythium root rot of Chrysanthemum in small-scale hydroponic units. Phytoparasitica 35: 159-178.

Ogai R, Fukuoka M, Suda W, Usami T, Amemiya Y 2009. Suppressive effect of microbial suspension prepared from compost-amended soil on bacterial wilt disease of tomato in a hydroponic system. HortResearch 63: 19-26.

Rankin L, Paulitz TC 1994. Evaluation of rhizosphere bacteria for biological control of Pythium root rot of greenhouse cucumbers in hydroponic culture. Journal of Plant Disease 78: 447-451.

Schisler DA, Slininger PJ, Behle RW, Jackson MA 2004. Formulation of Bacillus spp. for biological control of plant diseases. Phytopathology 94: 1267-1271.

Zhao ZH, Kusakari SI, Okada K, Miyazaki A, Osaka T 2000. Control of Pythium root rot on hydroponically grown cucumbers with silver-coated cloth. Bioscience Biotechnology and Biochemistry 64: 1515-1518.

Zuberer DA 1994. Recovery and enumeration of viable bacteria. In: Weaver RW, Angle S, Bottomley P, Bezdicek D, Smith S, Tabatabai A, Wollum, A ed. Methods of Soil Analysis: Part 2, Microbiological and Biochemical Properties, Number 5 in Soil Science Society of America Book series. Soil Science Society of America Inc., Wisconsin. Pp. 119-143. 